\title{
Soil ecophysiological and microbiological indices of soil health: a study of coal mining site in Sonbhadra, Uttar Pradesh
}

\author{
N. Upadhyay ${ }^{1}$, S. Verma ${ }^{1}$, A. Pratap Singh ${ }^{1}$, S. Devi ${ }^{1}$, K. Vishwakarma ${ }^{1}$, N. Kumar ${ }^{1}$, A.

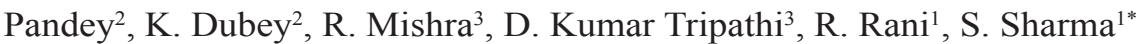

${ }^{1}$ Department of Biotechnology. Motilal Nehru National Institute of Technology Allahabad, 2(U.P.)-211004, India. ${ }^{2}$ Centre for Social Forestry and Eco-Rehabilitation, Allahabad, India. ${ }^{3}$ Centre for Medical Diagnostic and Research, MNNIT Allahabad, India.*Corresponding author: shiveshs@mnnit.ac.in,ssnvsharma@gmail.com

\begin{abstract}
The present study involves the discovery of quality of soils associated with dump mines and native forest encompassing the Kakari mine, a coal mining site in Sonbhadra, to distinguish the effect of coal mining on associated soil ecosystem. Soil ecophysiological indicator of the site was analyzed in terms of floral diversity by method of quadrat analysis, which revealed that dumps were devoid of any floral community whereas the natural forest around the mines was enriched with a number of plant species. Importance value index (IVI) was calculated and with respect to their IVI index the tree species viz., Acacia mangium $(23.17,24.48 \& 26.81)$ and Acacia catechu $(20.34,22.10 \& 25.36)$ were found to be the most dominant species. Soil enzymatic and physico-chemical analysis were analyzed by standard method and the result emphasized that dump soils possess poor enzymatic activity and acidic $\mathrm{pH}$ due to the decomposition of waste material in dumps which eventually affects the microbial diversity of soil and its fertility. The plant growth promotion (PGP) and stress tolerance characteristics of bacterial isolates were further examined so that the potential isolates will be utilized further to reclaim and remediate soil property of degraded soils. The promising isolates were characterized by BIOLOG identification system and isolate NU36 and NU25 showed greatest similarity with Pseudomonas sp. and Acinetobacter sp. respectively. Based on the potential to produce plant growth promoting substances and withstand in stressed environment the most promising isolates will be used to remediate soil and reclaim soil characteristics.
\end{abstract}

Keywords: Coal mining, dump, floral diversity, soil enzyme activities, IVI, BIOLOG 


\section{Introduction}

Coal is an important fossil fuel which is involved in the production of power and energy all over the world. Coal mining processes affect the surrounding environment by polluting the nearby water, soil and agriculture lands (Harun et al., 2014). Mining activity generates an extensive amount of waste material which gets deposited on the surface and destroys soil nutritional and functional properties by disrupting soil microbial population, texture, organic matter and mineral components (Bell et al., 2001). It leads to the degradation of existing natural vegetation, ecological communities, water quality, agricultural and forest lands. The opencast coal mining technique involves the deposition of overburden material and other pollutants which make the soil nutritionally and microbiologically deprived eventually leads to the removal of green cover, top soil and organic matter. The soil debris is heaped in the form of dumps and classified as mine spoil (Chaulya et al., 2000). The continuous mining process cause the removal of plant species, make the soil unfertile and creates environmental pollution by degrading soil, water and air. Hence, it is a major concern to evaluate the soil quality and vegetation status of the soil surrounding the coal mines and this will be helpful in identifying the impact of coal mining on the surrounding environment. Floral diversity is greatly affected by the soil properties. Numerous researches proved the adverse effect of mining on plant life and soil quality (Wong, 2003; Borpujari, 2008; Hossain et al., 2015). Soil characteristics are recovered by restoring the ecosystem conditions which can be done by revegetating the dump mines. It has been important to restore the land ecosystem by the revegetation of mine dumps. A number of approaches are available for the revegetation of coal mine dumps; most suitable is the use of native and indigenous plant species with the help of microbes found in the vicinity of plant roots. Several reports are available on the natural succession of different plant species on the barren dumps after certain interval of time (Benidire et al., 2016; Borpujari, 2008; Hazarika et al., 2006) but the process of natural succession usually proceeds at slow rate.

The process of reclamation involves the returning of the degraded land to near about its original stage by restoring the nutritional property of soil through revegetating the land. For a successful revegetation the selection of appropriate plant species is very important. The biorestoration involves the use of native plant applied with the rhizospheric microbes which involves the establishment of stable biogeochemical cycle and improves soil quality. The restoration of vegetation cover on the overburden dumps of coal mines will be helpful for human beings by stabilizing soil structure and property and make it nutritionally rich so that it creates less harm to the environment (Wong, 2003). It will make the ecosystem healthy by creating proper vegetation and improving soil structure and quality so that it can supports plant growth and reduces pollution.

Ecoremediation technology based on the management of plant microbe soil interactions is useful for the reclamation of soil ecosystems degraded by either mining or industrial activities. Plant-soil interactions are important for understanding the role of biotic abiotic factors in the functioning the degraded ecosystem, but very few knowledge is available related to these interactions, in the context of ecosystem restoration and succession (Merino et al., 2015). The natural habitat of the belonging site are utilized for the remediation of contaminated and dump soil. With this background, the present study is envisaged to examine soil characteristics and select the most dominant tree species with the potential microbes which will be helpful for the effective reclamation and remediation of the degraded soil. 


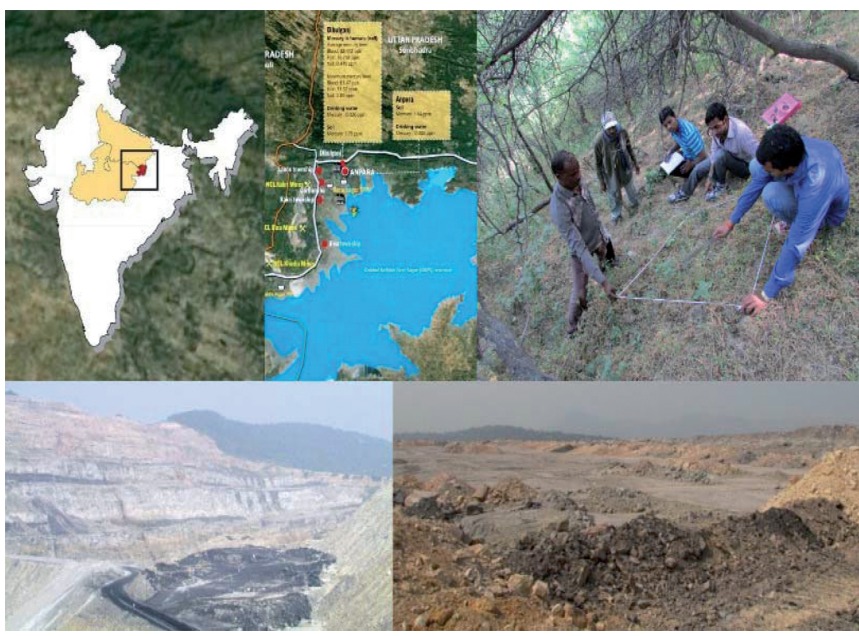

Figure 1. Location of the study site: (a) Kakri mine in Sonbhadra district (b) plant diversity analysis by quadrat method; (c) coal dumps in the mining area

\section{Materials and Methods}

\subsection{Study site and sampling}

The study site is situated in the Sonbhadra district of Uttar Pradesh at $27.68^{\circ} \mathrm{N}$ latitude and $83.06^{\circ} \mathrm{N}$ longitude. A representative area with mine tailings and dumps in the southern part of the Sonbhadra was surveyed and suitable sites were selected. Kakari mines

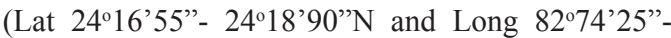
$\left.82^{\circ} 76^{\prime} 72^{\prime \prime} \mathrm{E}\right)$, an open mine developed by the Northern Coalfields Limited located beside the Govind Ballabh Pant Sagar reservoir was selected for plant diversity analysis as well as for collection of soil samples (Figure 1). The native forest nearby the coal mine area and the mine dump sites were surveyed for analyzing floristic composition in the area. Three sampling sites representing various categories of natural forest were selected for investigating vegetation and sampling. The vegetation status of the selected site was investigated by quadrat method. At each site five different quadrat of size $10 \mathrm{~m} \times 10 \mathrm{~m}, 3 \mathrm{~m} \times 3 \mathrm{~m}$ and $1 \mathrm{~m} \times$ $1 \mathrm{~m}$ were selected for trees, shrub and herb species respectively (Figure 1). For each quadrat, individuals of trees, shrubs and herbs were counted and the information was collected for further identification. The data collected were analyzed to calculate frequency, density, abundance, and importance value index (IVI) for each quadrat as per method described by Curtis and McIntosh (1950) to select the predominant species in the area. Abundance to frequency $(\mathrm{A} / \mathrm{F})$ ratio indicated as Whitford's index was calculated to examine the species distribution pattern in the forest and classified into three different pattern i.e. into regular $(<0.025)$, random $(0.025-0.05)$ and contagious $(>$ 0.05 ) (Whitford, 1949). The species diversity was determined by Shannon Weiner diversity index $\left(\mathrm{H}^{\prime}\right)$ and Simpson's diversity Index (Munishi, 2008).

Soil samples collected were collected in triplicate from both from the native and degraded soils of Kakri mine. Native soils (NF1-NF6) were belonged to the rhizospheric and non-rhizospheric regions of the dominant plant found in the natural forest contiguous to the mining sites in addition dump soils (DM1-DM4) belonged to the various dumps developed by the mining processes. Dump soils were collected from the 
depth of 9-10 inches where as the rhizospheric soils were collected from the soil around the root up to a depth of $15-20 \mathrm{~cm}$ and all the soil samples were carefully stored in plastic bags at $4{ }^{\circ} \mathrm{C}$ for further analysis. The number of microorganism in the soil sample was determined by standard spread plate count method technique by the surface inoculation on appropriate culture media. The bacterial colonies from soil samples were isolated by serial dilution plaiting on nutrient agar medium (Harley and Prescott, 2002). The plates were then incubated at $28^{\circ}$ for $24-48 \mathrm{~h}$. The bacterial colonies were then observed and the distinct colonies were streaked to obtained fresh culture. For isolation of fungus, soil samples $(1 \mathrm{~g})$ were serially diluted and plated on rose bengal chloroamphenicol agar medium. The plates were then observed for growth after incubation period of 7 days at a temperature of $25^{\circ} \mathrm{C}$. Total viable bacterial and fungal count were calculated and expressed in CFU.g ${ }^{-1}$. The bacterial isolates were further examined for their biochemical profiling by BIOLOG identification system (Biolog, Hayward, CA, USA). The $24 \mathrm{hr}$ old bacterial culture growing on biolog universal agar (BUG) medium was inoculated into the inoculating fluid (IF) and further incubated for 18-22 hr into Biolog GEN III plate. After the complete incubation the plates were read automatically with the Biolog OmniLog® ID System.

\subsection{Analysis of soil physico-chemical and enzymatic activity}

Soil samples were analyzed for physiochemical parameters like soil texture, $\mathrm{pH}$, electrical conductivity, organic carbon, available phosphorus and available potassium content. Soil texture analysis included the estimation of clay $(<0.002 \mathrm{~mm})$, silt $(0.06 \mathrm{~mm}-0.002$ $\mathrm{mm})$ and sand $(2 \mathrm{~mm}-0.06 \mathrm{~mm})$ percentage. The texture, $\mathrm{pH}$, electrical conductivity and organic carbon of the soil samples was determined by using the standard procedure as described by Kalra and Maynard (1991) and the level of available phosphorus and available potassium concentration was determined using Bray method (Simonis \& Setatou, 1996).

Soil dehydrogenase and phosphatase activities were determined by the procedure described by Tabatabai (1982). Soil dehydrogenase activity was calculated by using 2, 3, 5-trphenyl tetrazolium chloride (TTC) as a substrate. The substrate was reduced to triphenyl formazan (TPF) a red colored compound which was measured calorimetrically at a wavelength of 485 $\mathrm{nm}$. The concentration of TPF produced was determined by using of standard curve and expressed as $\mu$ g TPF.g ${ }^{-1}$ dry soil $h^{-1}$ over control. Soil phosphatase activity was measured using p-nitro phenyl phosphate as a substrate and was expressed as mg p-nitrophenol (pNP) per gram dry soil and incubation time. Urease activity was calculated by the procedure described by Kandeler \& Gerber (1988) using urea as a substrate. The concentration of ammonia produced was determined by colorimetric method and expressed as mg $\mathrm{NH}_{4}^{+}-\mathrm{N}$ released/ (g dry soil. $24 \mathrm{hr}$ ). Catalase activity was measured by $\mathrm{KMnO}_{4}$ titration method with $\mathrm{H}_{2} \mathrm{O}_{2}$ as substrate and expressed in $0.1 \mathrm{~mol} / \mathrm{L} \mathrm{KMnO}_{4}$ solution titrated/ (g dry soil•20 min) (Zhan et al., 2010).

\subsection{Characterization of bacteria for plant growth promotion and stress tolerance}

The isolated bacterial colonies were screened for various plant growth promotion characteristics as well as for their survival in harsh environmental conditions. IAA production was estimated both qualitatively and quantitatively according to the method described by Loper and Schroth (1986) by Salkowski method. The amount of IAA produced in culture medium was calculated by comparing it with standard curve in $\mathrm{mg} /$ $\mathrm{ml}$. Bacterial isolates were screened for phosphate solubilization ability on Pikovskaya's (PVK) agar 
medium containing tri-calcium phosphate (TCP) as a substrate (Premono et al., 1996). Siderophore production was examined by CAS assay; chrome azurol $\mathrm{S}$ agar medium was prepared according to the composition described by Schwyn and Neilands (1987). Single colonies of bacterial isolates were spot inoculated and incubated at $28{ }^{\circ} \mathrm{C}$ for 2 weeks. The colonies with orange zones were considered as siderophore producing strains.

The isolates were screened for drought tolerance as per the method described by Sandhya et al., (2009). Nutrient broth medium amended with different concentration of PEG 6000 having water potentials of $-0.0573 \mathrm{MPa},-0.1573 \mathrm{MPa},-0.3073 \mathrm{MPa},-0.4973$ $\mathrm{MPa},-0.73 \mathrm{MPa}$ and $-1.2 \mathrm{MPa}$ was inoculated with $1 \%$ of bacterial culture cultivated overnight in nutrient broth. The tubes were then incubated at 28-30 ${ }^{\circ} \mathrm{C}$ and $\mathrm{OD}$ was recorded at $600 \mathrm{~nm}$ after $24-48 \mathrm{~h}$. The isolates were tested for temperature resistance by incubating the bacterial isolates at different temperature ranged between $10{ }^{\circ} \mathrm{C}$ to $50{ }^{\circ} \mathrm{C}$ for $24 \mathrm{hr}$. Salt tolerance potential of isolates was screened by growing the bacteria isolates in medium having salt concentration from $0.5 \%$ to $15 \%$. Isolates were further screened for $\mathrm{pH}$ tolerance by growing the bacterial culture within a range of $\mathrm{pH} 4-\mathrm{pH} 10$ (Joshi and Modi, 2013). The selected bacterial isolates were tested for metal resistance. The 24 hour old grown bacterial cultures were incubated in nutrient broth amended with metal salt viz., cadmium chloride $\left(\mathrm{CdCl}_{2}\right)$, lead chloride $\left(\mathrm{PbCl}_{2}\right)$, and zinc chloride $\left(\mathrm{ZnCl}_{2}\right)$ at various concentration ranged between 1 $\mathrm{mM}$ to $10 \mathrm{mM}$, the inoculated broth was then incubated at $28{ }^{\circ} \mathrm{C}-30{ }^{\circ} \mathrm{C}$ for $24-48$ hours and absorbance of the sample were taken at $600 \mathrm{~nm}$. Bacterial isolates were considered stress tolerant if an OD of 0.1 or above was recorded.

\subsection{Statistical analysis}

All the data obtained were statistically analyzed and presented with the appropriate standard deviation and standard error method. The data obtained from the assessment of physicochemical and enzymatic activities for various soil samples were analyzed for correlation analysis to obtain the level of significance between them. The Pearson's correlation coefficient for all the variables was calculated to determine the linear correlations between them. The data analysis and preparation of graphs was done by using the software OriginLab- OriginPro 8. 3.

\section{Results}

\subsection{Floral diversity}

The natural forest around the coal mine as well as the mine spoil was surveyed for analyzing the existing natural vegetation. The survey revealed that no vegetation cover was observed on the mine spoil due to the adverse environmental conditions. A total of 25 plant species were identified in the forest around the mining site belonging to 23 genera and 15 families. Among the 25 plant species, 16 species were represented by trees (Woodfordia fruticosa, Lagistomia parviflora, Acacia catechu, Acacia mangium, Dalbergia sissoo, Leucaena leucocephala, Acacia auriculiformis, Solanum nigrum, Boswellia sacra, Azadirachta indica, Diospyros melanoxylon, Milius tometosa, Manilkara hexandra, Murraya paniculata, Chloroxylon swietenia and Bambusa strictus), 5 species by shrubs (Lantana camara, Achyranthes aspera, Sida cordifolia, Bromus tectorum and Peristrophe paniculata) and the remaining 4 species were represented by herbaceous species (Plumbago zeylanica, Sacarum spontanium, Cynodon dactylon 
and Eragrostis japonica); majority of the plant species belonged to the family Poaceae, Fabaceae and Rutaceae. Tree species were selected for the further studies and the data obtained from the quantitative analysis of trees are presented in Table 1a-b1. Importance value index (IVI) value indicates that Acacia mangium is the most dominantly growing species having IVI value in site I, II \& site III $(23.17,24.48$ \& 26.81) followed by Acacia catechu $(20.34,22.10$ \& 25.36). Maximum density $\left(4.4 / 100 \mathrm{~m}^{2}, 2.4 / 100 \mathrm{~m}^{2} \&\right.$ $2.2 / 100 \mathrm{~m}^{2}$ ) is recorded for Acacia mangium in each of the three study sites respectively among the other tree species. The respective IVI index value for different trees is given in Table 1a-1b. Importance value index provides the information of important and dominant plant species in a plant community. ShannonWiener Index $\left(\mathrm{H}^{\prime}\right)$ and Simpson's index was calculated for the different sites. Both the Shannon wiener and Simpson's diversity index was highest in site I $(2.70,0.93)$ with reference to site II $(2.45,0.92)$ and site III $(2.36,0.91)$ which indicates the presence of immense species diversity of trees in the site I. Simpson's Diversity Index calculate diversity by considering both richness and evenness of the species and the index value ranges between 0 to 1 which signifies that every species came across belonged to different species. The overall distribution pattern observed for site I, II and III are regular and random distribution pattern for all the encountered species and presented in Table 1a-1b.

\subsection{Microbial diversity}

Soil microorganism are primarily involved in maintaining the ecosystem functions and are responsible for the transformation of soil nutrients and organic matter (Merino et al., 2015). The result obtained from the study is presented in Figure 2 (a) and it is evident that the highest bacterial diversity was observed in the rhizospheric soils as compared to the non rhizospheric soils and to the dump soils. The cfu for bacteria obtained from the native soils ranged from $103.33 \times 10^{5}$ $\mathrm{g}^{-1}$ in NF1 to $323.67 \times 10^{5} \mathrm{~g}^{-1}$ in NF2 for rhizosphere, $42.67 \times 10^{5} \mathrm{~g}^{-1}$ to $142.72 \times 10^{5} \mathrm{~g}^{-1}$ for non- rhizospheric and for mined soil it ranged from $6.4 \times 10^{3} \mathrm{~g}^{-1}$ to $9.22 \times 10^{3} \mathrm{~g}^{-1}$. For soils collected from native forest, maximum bacterial count was recorded in soil sample NF2 indicating the presence of immense bacterial population in comparison with the other soils (Figure 2a). On comparing dump soils to native soils, high microbial diversity is observed in native soil. A total sixty four bacterial isolates were obtained which were further screened for different plant growth promotion and stress tolerant mechanism. The number of fungi obtained from rhizospheric soil is ranged from $2.66 \times 10^{2} \mathrm{~g}^{-1}$ in NF3 to $35.67 \times 10^{2} \mathrm{~g}^{-1}$ in NF1 (Figure 2b). For the rhizospheric soils and the non rhizospheric soils highest fungal count was recorded in the rhizospheric soil.

\subsection{Physicochemical analysis and enzyme activities of soil}

The data obtained from the particle size distribution, textural classification and physicochemical analysis of soil samples from dump and natural forest is presented in Table 2. Soil fertility is coupled with soil $\mathrm{pH}$ and an alkaline $\mathrm{pH}$ suggests a healthy soil suitable for plant growth (Maharana et al., 2013). The growth of plant suffers much both under very low as well as high $\mathrm{pH}$. To enumerate the current condition of soil, samples were analyzed for $\mathrm{pH}$ testing. In the present work, the dump soils retain an acidic $\mathrm{pH}$ (5.39-6.29) indicating a less fertile soil where as soils NF1 and NF4 possess an alkali $\mathrm{pH}(7.27,7.06)$ which is advantageous for vegetation sustainability. The $\mathrm{pH}$ of soil is positively correlated with the clay content $(r=0.662$; 
Table 1a. Quantitative Structure of tree species in the study area for Site I, Site II and Site III

\begin{tabular}{|c|c|c|c|c|c|}
\hline \multicolumn{6}{|c|}{ SITE I } \\
\hline S. No. & Trees & Density & IVI & $\mathrm{W}(\mathrm{A} / \mathrm{F}$ ratio $)$ & $\begin{array}{c}\text { Distribution } \\
\text { pattern }\end{array}$ \\
\hline 1 & $\begin{array}{c}\text { Woodfordia } \\
\text { fruticosa }\end{array}$ & 1.2 & 10.31 & 0.018 & Regular \\
\hline 2 & $\begin{array}{l}\text { Lagistomia } \\
\text { parviflora }\end{array}$ & 1.2 & 10.31 & 0.018 & Regular \\
\hline 3 & Acacia catechu & 3.6 & 20.34 & 0.036 & Random \\
\hline 4 & Acacia mangium & 4.4 & 23.17 & 0.044 & Random \\
\hline 5 & Dalbergia sissoo & 1.6 & 11.73 & 0.025 & Random \\
\hline 6 & $\begin{array}{c}\text { Leucaena } \\
\text { leucocephala }\end{array}$ & 1 & 9.67 & 0.015 & Regular \\
\hline 7 & $\begin{array}{c}\text { Acacia } \\
\text { auriculiformis }\end{array}$ & 1 & 8.09 & 0.027 & Random \\
\hline 8 & Manikara hexandra & 1.2 & 10.31 & 0.018 & Regular \\
\hline 9 & $\begin{array}{c}\text { Murraya } \\
\text { paniculata }\end{array}$ & 1.6 & 11.73 & 0.025 & Random \\
\hline 10 & $\begin{array}{c}\text { Chloroxylon } \\
\text { swietenia }\end{array}$ & 3.2 & 18.92 & 0.032 & Random \\
\hline 11 & Solanum nigrum & 1.2 & 10.31 & 0.018 & Regular \\
\hline 12 & Azadirachta indica & 1.4 & 11.02 & 0.021 & Regular \\
\hline 13 & Boswellia sacra & 0.8 & 7.38 & 0.022 & Regular \\
\hline 14 & $\begin{array}{c}\text { Diospyros } \\
\text { melanexylon }\end{array}$ & 2.8 & 17.5 & 0.028 & Random \\
\hline 15 & Milius tometosa & 1.4 & 12.54 & 0.014 & Regular \\
\hline 16 & Bambusa strictus & 0.6 & 6.67 & 0.016 & Regular \\
\hline
\end{tabular}


Table 1b. Quantitative Structure of tree species in the study area for Site I, Site II and Site III

\begin{tabular}{|c|c|c|c|c|c|}
\hline \multicolumn{6}{|c|}{ SITE II } \\
\hline 1. & $\begin{array}{l}\text { Woodfordia } \\
\text { fruticosa }\end{array}$ & 1 & 14.11 & 0.015 & Regular \\
\hline 2. & Acacia catechu & 2 & 22.10 & 0.02 & Regular \\
\hline 3. & Acacia mangium & 2.4 & 24.48 & 0.024 & Regular \\
\hline 4. & Dalbergia sissoo & 0.8 & 10.88 & 0.022 & Regular \\
\hline 5. & $\begin{array}{l}\text { Leucaena } \\
\text { leucocephala }\end{array}$ & 1.4 & 16.49 & 0.021 & Regular \\
\hline 6. & Manikara hexandra & 1.4 & 16.49 & 0.021 & Regular \\
\hline 7. & $\begin{array}{l}\text { Murraya } \\
\text { paniculata }\end{array}$ & 1.2 & 13.26 & 0.033 & Random \\
\hline 8. & $\begin{array}{l}\text { Chloroxylon } \\
\text { swietenia }\end{array}$ & 1.6 & 19.72 & 0.016 & Regular \\
\hline 9. & Solanum nigrum & 1.2 & 15.30 & 0.018 & Regular \\
\hline 10. & $\begin{array}{l}\text { Diospyros } \\
\text { melanexylon }\end{array}$ & 1.8 & 20.91 & 0.018 & Regular \\
\hline 11. & Milius tometosa & 1.2 & 15.30 & 0.0187 & Regular \\
\hline 12. & Bambusa strictus & 0.8 & 10.88 & 0.022 & Regular \\
\hline \multicolumn{6}{|c|}{ SITE III } \\
\hline 1. & $\begin{array}{l}\text { Woodfordia } \\
\text { fruticosa }\end{array}$ & 1 & 15.94 & 0.0156 & Regular \\
\hline 2. & $\begin{array}{l}\text { Lagistomia } \\
\text { parviflora }\end{array}$ & 1.2 & 10.31 & 0.018 & Regular \\
\hline 3. & Acacia catechu & 2 & 25.36 & 0.02 & Regular \\
\hline 4. & Acacia mangium & 2.2 & 26.81 & 0.022 & Regular \\
\hline 5. & Dalbergia sissoo & 0.8 & 14.49 & 0.0125 & Regular \\
\hline 6. & $\begin{array}{l}\text { Leucaena } \\
\text { leucocephala }\end{array}$ & 1 & 13.76 & 0.0277 & Random \\
\hline 7. & $\begin{array}{l}\text { Murraya } \\
\text { paniculata }\end{array}$ & 1.2 & 19.56 & 0.012 & Regular \\
\hline 8. & $\begin{array}{l}\text { Chloroxylon } \\
\text { swietenia }\end{array}$ & 1.4 & 21.01 & 0.014 & Regular \\
\hline 9. & Solanum nigrum & 0.6 & 10.86 & 0.016 & Regular \\
\hline 10. & $\begin{array}{l}\text { Diospyros } \\
\text { melanexylon }\end{array}$ & 1.6 & 20.28 & 0.025 & Random \\
\hline 11. & Milius tometosa & 1 & 15.94 & 0.015 & Regular \\
\hline 12. & Bambusa strictus & 1 & 15.94 & 0.015 & Regular \\
\hline
\end{tabular}


(a)
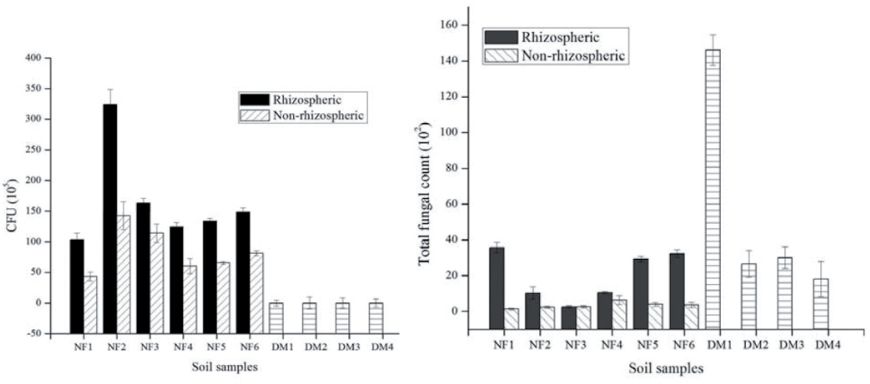

(b)
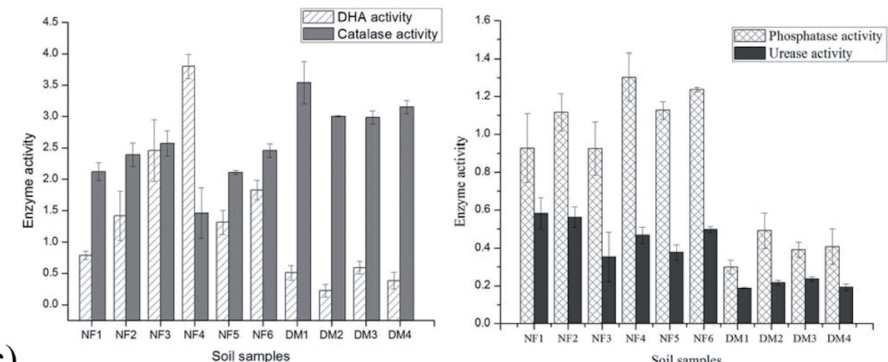

(d)

Figure 2. Comparative analysis of microbial diversity and enzyme activity for both the native and dump soils (a) Total viable bacterial count and (b) fungal count for native (rhizospheric \& non rhizospheric) (c) DHA and Catalase activity (d) Phosphatase and Urease activity

Table 2. Soil sample analysis with respect to soil texture and physico-chemical parameters

\begin{tabular}{|c|c|c|c|c|c|c|c|c|c|}
\hline $\begin{array}{c}\text { Soil } \\
\text { sample }\end{array}$ & $\%$ Sand & $\%$ Silt & $\%$ Clay & $\begin{array}{c}\text { Soil } \\
\text { texture }\end{array}$ & pH & $\begin{array}{c}\text { Electrical } \\
\text { conductivity }\end{array}$ & $\begin{array}{l}\text { Organic } \\
\text { carbon }\end{array}$ & $\begin{array}{c}\text { Available } \\
\text { phosphors } \\
\text { (Kg/ha) }\end{array}$ & $\begin{array}{c}\text { Available } \\
\text { potassium } \\
\text { (Kg/ha) }\end{array}$ \\
\hline NF1 & $46.33 \pm 3.05$ & $24.73 \pm 1.16$ & $28.93 \pm 3.78$ & Clay loam & $7.27 \pm 0.06$ & $0.22 \pm 0.02$ & $0.43 \pm 0.015$ & $33.02 \pm 1.06$ & $123.78 \pm 1.68$ \\
\hline NF2 & $44.23 \pm 2.04$ & $26.33 \pm 2.25$ & $29.43 \pm 3.97$ & Clay loam & $5.58 \pm 0.47$ & $0.14 \pm 0.01$ & $0.94 \pm 0.04$ & $32.31 \pm 1.94$ & $172.28 \pm 1.85$ \\
\hline NF3 & $46.8 \pm 2.52$ & $28.23 \pm 1.34$ & $24.96 \pm 2.01$ & Loam & $5.93 \pm 0.20$ & $0.48 \pm 0.01$ & $0.60 \pm 0.01$ & $86.11 \pm 1.4$ & $135.22 \pm 3.5$ \\
\hline NF4 & $45.4 \pm 3.245$ & $27.06 \pm 1.30$ & $27.53 \pm 3.76$ & $\begin{array}{c}\text { Sandy clay } \\
\text { loam }\end{array}$ & $7.06 \pm 0.20$ & $0.23 \pm 0.02$ & $0.81 \pm 0.011$ & $36.03 \pm 0.36$ & $156.71 \pm 2.02$ \\
\hline NF5 & $45 \pm 4.04$ & $27 \pm 4.58$ & $28 \pm 2.64$ & Loam & $6.93 \pm 0.45$ & $0.27 \pm .01$ & $0.86 \pm .01$ & $56.66 \pm 2.08$ & $128.33 \pm 3.05$ \\
\hline NF6 & $39.33 \pm 2.51$ & $29 \pm 2.00$ & $31.66 \pm 2.08$ & Clay loam & $6.33 \pm 0.37$ & $0.24 \pm .02$ & $0.64 \pm .01$ & $44.66 \pm 2.51$ & $132.66 \pm 1.52$ \\
\hline DM1 & $67.67 \pm 3.21$ & $17.76 \pm 1.32$ & $14.56 \pm 4.39$ & $\begin{array}{l}\text { Sandy } \\
\text { loam }\end{array}$ & $5.4 \pm 0.18$ & $0.55 \pm 0.01$ & $0.59 \pm 0.01$ & $31.71 \pm 1.94$ & $93.48 \pm 1.43$ \\
\hline DM2 & $52.76 \pm 1.96$ & $20.56 \pm 0.68$ & $26.66 \pm 1.36$ & $\begin{array}{c}\text { Sandy clay } \\
\text { loam }\end{array}$ & $6.29 \pm 0.19$ & $0.54 \pm 0.02$ & $0.65 \pm 0.01$ & $26.81 \pm 1.00$ & $87.97 \pm 0.84$ \\
\hline DM3 & $55.42 \pm 2.10$ & $23.69 \pm 1.18$ & $20.79 \pm 2.05$ & $\begin{array}{c}\text { Sandy clay } \\
\text { loam }\end{array}$ & $5.39 \pm 0.21$ & $0.51 \pm 0.02$ & $0.61 \pm 0.02$ & $29.15 \pm 1.17$ & $89.24 \pm 0.91$ \\
\hline DM4 & $59.09 \pm 2.21$ & $21.40 \pm 2.22$ & $19.50 \pm 1.90$ & $\begin{array}{c}\text { Sandy clay } \\
\text { loam }\end{array}$ & $5.45 \pm 0.20$ & $0.52 \pm 0.01$ & $0.54 \pm 0.01$ & $28.05 \pm 1.07$ & $96.46 \pm 1.32$ \\
\hline
\end{tabular}


The maximum EC value was found in dump soils as compared to other soil samples which can be toxic to plants and may prevent them from obtaining water from the soil. It was observed from the data that electrical conductivity was positively correlated with the sand content and negatively correlated with silt and clay content (Table 3). Organic carbon is referred to the amount of carbon recovered from microorganism and plant found in the soil and according to Ghosh et al., (1983) soil having $0.8 \%$ organic carbon is referred to as healthy soil and for soil having percentage of organic carbon 0.4 or below that referred as poor quality of soil i.e. deficient in proper nutrient and microbes. The percentage of organic carbon for the given soil samples was found to be in the range of $0.43 \%$ (NF1) to $0.94 \%$ (NF2). The result shows that dump soils have $\mathrm{pH}$ in the range of $0.54 \%$ to $0.65 \%$, which indicates an average quality of soil. Sample NF4 and NF2 has percentage of organic carbon above 0.8 signifies a healthy soil which support plant and microbial growth. It was reported that soil particles influence organic carbon (OC) in soil and in coordination they promote formation of soil aggregates maintain soil stability and nutrient holding ability, thus considered as an important indicator of soil fertility (Maharana et al., 2013 ; Rajan et al., 2010). The available phosphorus content ranged from $26.81 \mathrm{Kg}$ /ha to 86.11 $\mathrm{Kg} / \mathrm{ha}$. The available phosphorus was highest in NF3; whereas the lowest concentration of available phosphorus was found in the DM2. The available K concentration ranged from $87.97 \mathrm{Kg} / \mathrm{ha}$ (DM2) to 172.28 $\mathrm{Kg} / \mathrm{ha}$ (NF2). The available potassium content was positively correlated with the organic carbon content $(0.677, p<0.05)$ (Table 3)

Table 3. Pearson correlation coefficient between different soil properties

\begin{tabular}{|c|c|c|c|c|c|c|c|c|c|c|c|c|c|}
\hline & $\mathrm{CFU}$ & DHA & Phosphatase & Urease & Catalase & $p H$ & $E C$ & Sand & Silt & Clay & $\mathrm{OC}^{+}$ & $\overline{A P^{+}}$ & $A \boldsymbol{K}^{+}$ \\
\hline CFU & 1 & & & & & & & & & & & & \\
\hline DHA & 0.558 & 1 & & & & & & & & & & & \\
\hline Phosphatase & $0.864^{* * *}$ & $0.749^{* *}$ & 1 & & & & & & & & & & \\
\hline Urease & $0.83^{* *}$ & 0.496 & $0.864^{* *}$ & 1 & & & & & & & & & \\
\hline Catalase & $-0.652 *$ & $-0.766 * *$ & $-0.881 * *$ & $-0.778 * *$ & 1 & & & & & & & & \\
\hline pH & 0.185 & 0.217 & 0.446 & 0.458 & -0.484 & 1 & & & & & & & \\
\hline EC & $-0.799^{* * *}$ & -0.287 & $-0.735^{* * *}$ & $-0.818^{* *}$ & 0.496 & $-0.577^{*}$ & 1 & & & & & & \\
\hline Sand & $-0.726^{* * k}$ & -0.55 & $-0.889^{* * *}$ & $-0.805^{* * *}$ & $0.766^{* * *}$ & $-0.603^{*}$ & $0.792^{* * *}$ & 1 & & & & & \\
\hline Silt & $0.715^{* *}$ & $0.750^{* *}$ & $0.907 * *$ & $0.744^{* * *}$ & $-0.826 * *$ & 0.448 & $-0.688 *$ & $-0.921 * *$ & 1 & & & & \\
\hline Clay & $0.668 *$ & 0.361 & $0.795 * *$ & $0.772^{* *}$ & $-0.654 *$ & $0.656^{*}$ & $-0.791 * *$ & $-0.962 * *$ & $0.779^{* *}$ & 1 & & & \\
\hline OC & $0.63^{*}$ & 0.239 & 0.424 & 0.174 & -0.156 & 0.055 & -0.502 & -0.393 & 0.377 & 0.369 & 1 & & \\
\hline $\mathbf{A P}^{+}$ & 0.363 & $0.837^{* *}$ & $0.658^{*}$ & 0.367 & $-0.794^{\text {* * * }}$ & 0.146 & -0.032 & -0.386 & $0.594^{*}$ & 0.207 & 0.076 & 1 & \\
\hline $\mathbf{A K}^{+}$ & $0.933^{* *}$ & $0.642 *$ & $0.833^{* * *}$ & $0.771^{* * *}$ & $-0.618^{*}$ & 0.356 & $-0.852 * *$ & $-0.735 * *$ & $0.748^{* * *}$ & $0.662 *$ & $0.635 *$ & 0.323 & 1 \\
\hline
\end{tabular}

\footnotetext{
$* *$ Correlation is significant $p<0.01$ and $*$ correlation is significant $p<0.05$

$\mathrm{OC}+$ - Organic carbon, $\mathrm{AP}^{+}$- Available phosphorus, $\mathrm{AK}^{+}$- Available potassium
} 
To enumerate soil biological activity, soil dehydrogenase, phosphatase, urease and catalase activity was calculated and compared for native soil and for the dump soils (Figure 2c \& 2d).

The dehydrogenase activity ranged between $0.22 \mu \mathrm{g}$ TPF.g $\mathrm{g}^{-1}$ dry soil $\mathrm{h}^{-1}$ to $3.79 \mu \mathrm{g}$ TPF. $\mathrm{g}^{-1}$ dry soil $\mathrm{h}^{-1}$ for different soil samples. The maximum dehydrogenase activity was found in the native soil sample of NF4 i.e. $3.79 \mu \mathrm{g}$ TPF. $\mathrm{g}^{-1}$ dry soil $\mathrm{h}^{-1}$ (Figure $2 \mathrm{c}$ ). In the present study dehydrogenase activity is positively correlated with the phosphatase activity $(\mathrm{r}=0.790, p<0.05)$ and soil silt percentage (Table 3 ). Dehydrogenase activity was found to be correlated with the bacterial diversity of soil whereas the current study shows that DHA activity is not significantly correlated with bacterial diversity which reflects that the mining activities alter the environmental conditions such as presence of metal contamination which may inhibit the dehydrogenase activity. The result draws support from the finding Oliveira and Maria, (2006) which stated that DHA activity is inhibited by the presence of heavy metal contamination in soils.

Catalase is an intracellular enzyme exists in the soil and organisms widely and responsible for the decomposition of plant litter and for the decomposition of $\mathrm{H}_{2} \mathrm{O}_{2}$. In soil, catalase activity has been greatly associated with the organic matter content. Maximum activity was found in dump soils and in rhizospheric soils of NF2. The catalase activity for various soil samples is shown in Figure 2c. Catalase activity recorded in dump soils was 3.54 $\mathrm{ml}$ of $0.1 \mathrm{M} \mathrm{KMnO} 4 / \mathrm{g}$ soil $/ \mathrm{h}$ and $3 \mathrm{ml}$ of $0.1 \mathrm{M}$ $\mathrm{KMnO} 4 / \mathrm{g}$ soil/h for DM1 and DM2 respectively (Figure 2c). Catalase activity ranged between 1.46 $\mathrm{ml}$ of $0.1 \mathrm{M} \mathrm{KMnO} 4 \mathrm{~g}$ soil/h to $3.54 \mathrm{ml}$ of $0.1 \mathrm{M}$ $\mathrm{KMnO} 4 / \mathrm{g}$ soil/h. The catalase activity is negatively correlated with the dehydrogenase activity and was found to be highest in dump soils which differ from the recent studies (Mitrovica et al., 2013). In comparison with phosphatase and urease, catalase activity is negatively correlated which indicate the presence of stress condition in soils of coal mine.

Urease enzyme involved in the hydrolysis of urea into ammonia and carbon dioxide and plays an important role in nitrogen cycling. Production of ammonia tends to increase soil $\mathrm{pH}$ and make soil alkaline in nature. Urease activity was found to be highest in the native soils in comparison with the degraded soils of dump. The maximum activity was found in the soil NF2 i.e. $0.583 \mu \mathrm{g} / \mathrm{NH}_{4}{ }^{+} / \mathrm{g} / 24$ h (Figure 2d). On comparing urease activity between different soil samples; least activity was recorded in dump. The current findings indicate that for these soils urease activity was not correlated with the organic carbon content which contradicts the findings of Tabatabai, (1977) who reported that urease activity was significantly correlated with organic carbon. The urease activity was significantly correlated with the phosphatase activity which showed the soil is in biochemically active conditions (Table 3 ).

Phosphatase enzyme plays an important role in phosphorus cycle and is correlated with plant growth. It was observed that dump soil has the minimum phosphatase activity. Maximum activities was recorded in the rhizospheric soil sample $\mathrm{NF} 4$ i.e. $1.30 \mu \mathrm{M} \mathrm{pNP} / \mathrm{g} / 24 \mathrm{hr}$ indicating highest microbial activity in the soil. The Phosphatase activity ranged from $0.29 \mu \mathrm{M} \mathrm{pNP} / \mathrm{g} / 24 \mathrm{hr}$ to 1.30 $\mu \mathrm{M} \mathrm{pNP} / \mathrm{g} / 24 \mathrm{hr}$ and presented in Figure $2 \mathrm{~d}$. The findings of the present study suggested that urease and phosphatase activity were found to be positively correlated with bacterial diversity and maximum activity was recorded for natural soils due to the presence of high bacterial diversity. 


\subsection{Screening of bacterial isolates for plant growth} promotion and stress resistance

The total bacterial isolates isolated from the dump soil as well as from the native soils of the dominant plant were screened for various plant growth promotion activity and stress tolerance potential. The native soil collected from rhizospheric and non rhizospheric regions of the dominantly growing plant viz., Acacia mangium \& Acacia catechu which has high bacterial population these bacterial isolates possessed maximum plant growth promotion activities. The range and percentage of positive isolates varied greatly for each plant growth promotion activities. A total of sixty four bacterial isolates screened for their plant growth promotion activities viz., Indole acetic acid (IAA) production, phosphate solubilization and siderophore production. Phosphate solubilization activity was screened qualitatively on the Pikovskaya's agar plates and bacterial isolates were selected for phosphate solubilization by the presence of a clear halo around the bacterial colony. In the current work 28 isolates were found to solubilize phosphate with a solubilization zone ranged between $2 \mathrm{~mm}$ to $13 \mathrm{~mm}$. It was observed that maximum phosphate solubilizing bacteria were associated with soil NF4. Isolates NU1, NU6, NU25, NU27, NU36 and NU47 were selected as the most efficient phosphate solubilizing bacteria having the solubilization zone between $6 \mathrm{~mm}-13$ $\mathrm{mm}$. The highest solubilization index was observed by NU36 with $13 \mathrm{~mm}$ of clear zone indicating phosphate solubilization. Bacterial isolates were further screened for the production of growth regulator i.e. IAA and it was found that majority of the isolates were positive for IAA production. The range of IAA produced by different bacterial isolates lies between $0.8 \mu \mathrm{g} / \mathrm{ml}$ to $77 \mu \mathrm{g} / \mathrm{ml}$ with an average concentration of $24.9 \mu \mathrm{g} / \mathrm{ml}$. Isolate NU25 was selected as the highest producer of IAA i.e. $77 \mu \mathrm{g} / \mathrm{ml}$. Very few isolates from dump soils were found to produce a significant concentration of IAA, isolate NU51 from the dump soil has produced a significant concentration of IAA. Bacterial isolates able to form an orange halo zone were selected as siderophore producer. A total of 3 bacterial isolates (NU36, NU27, and NU25) were found to produce siderophore. Within the $24 \mathrm{~h}$ of incubation significantly an average siderophore production was observed and it was increased within the incubation period of 4-5 days. An orange halo zone was observed around the bacterial colony which indicates siderophore production. The most promising isolates out of the total sixty four bacterial isolates having several plant growth promotion activities are presented in Table 4 .

The bacterial isolates were further screened for stress tolerance potential viz., drought, high temperature, salinity, $\mathrm{pH}$ and heavy metal. A total sixty four isolates were isolated and screened for drought resistance, out of which 51 isolates were grown at minimal water potential (-0.0573 MPa) i.e. 5\% PEG 6000. Bacterial isolates showing luxuriant growth at water potential -0.73 MPa (25\% PEG 6000) and -1.2 MPa (32.6\% PEG 6000) were selected as drought resistant bacteria (Figure 3a). It was observed that with the increasing concentration of PEG 6000 in the medium the concentration of bacterial cells got decreased. Bacterial isolates further screened for a temperature range of 10-50 ${ }^{\circ} \mathrm{C}$. A wide range of isolates were found to be grown at a temperature of $20-30{ }^{\circ} \mathrm{C}$. Least number of bacterial isolates was survived at a temperature of $10{ }^{\circ} \mathrm{C}$. Only three bacterial isolates NU3, NU19 and NU24 were able to tolerate the maximum temperature of 50 ${ }^{\circ} \mathrm{C}$. In the present study bacterial isolates growing at $40{ }^{\circ} \mathrm{C}$ were selected as temperature resistant. Further increase in temperature results in the decrease of bacterial growth. Furthermore, bacterial isolates screened for salt resistance within a salt concentration of 0.5 $\%-15 \%$. A maximum number of bacterial isolates were grown within the range of $0.5 \%-4 \%$ salt concentration. 
Table 4. Details of potential isolates with respect to PGP and stress tolerance potential and similarity index with neighboring bacterial species in biolog database

\begin{tabular}{|c|c|c|c|c|c|c|c|c|c|}
\hline & \multicolumn{4}{|c|}{ Plant growth promotion activities } & \multicolumn{3}{|c|}{ Stress tolerance potential } & \multicolumn{2}{|c|}{ Biolog } \\
\hline S.No. & $\begin{array}{c}\text { Isolate } \\
\text { Code }\end{array}$ & $\begin{array}{c}\text { IAA } \\
(\mu \mathrm{g} / \mathrm{ml})\end{array}$ & $\begin{array}{c}\text { Phosphate } \\
\text { (mm) }\end{array}$ & Siderophore & $\begin{array}{c}\text { Temperature } \\
\text { tolerant } \\
\left(40^{\circ} \mathrm{C}\right)\end{array}$ & $\begin{array}{c}\text { Salt } \\
\text { tolerant } \\
(10 \%)\end{array}$ & $\begin{array}{c}\mathrm{pH} \text { tolerant } \\
(6-8)\end{array}$ & $\begin{array}{c}\text { Neighboring } \\
\text { species in } \\
\text { biolog } \\
\text { database }\end{array}$ & $\begin{array}{c}\% \\
\text { Similarity }\end{array}$ \\
\hline 1. & NU25 & $77 \pm 3.60$ & 9 & ++ & H & H+ & +++ & Acinetobacter & 56.9 \\
\hline
\end{tabular}

spp.

\begin{tabular}{|c|c|c|c|c|c|c|c|c|c|}
\hline 2. & NU27 & $53 \pm 2.24$ & 6 & $+1+$ & + & +t & H+ & NA & - \\
\hline 3. & NU36 & $54.6 \pm 2.42$ & 8 & + & +++ & ++ & +++ & $\begin{array}{c}\text { Pseudomonas } \\
\text { spp. }\end{array}$ & 57.5 \\
\hline 4. & NU44 & $33.13 \pm 2.16$ & 13 & - & ++ & + & H+ & NA & - \\
\hline
\end{tabular}

-No growth, + Moderate growth/ Weak producer; ++ Good growth/Medium producer; +++ Excellent growth/Strong producer.

Out of 64 bacterial isolates nineteen isolates growing at a salt concentration of $10 \%$ were selected as salt tolerant and very few isolates were grown at maximum salt concentration $15 \% \mathrm{NaCl}$. $\mathrm{pH}$ tolerant bacterial isolates where then screened by growing bacteria within the range of $\mathrm{pH} 4-10$. Out of sixty four only four bacterial isolates (NU7, NU3 NU4, and NU24) were grown at $\mathrm{pH} 4$ and 18 isolates (NU2, NU34, NU55, NU21, NU7, NU30, NU3, NU19, NU23, NU27, NU46) were tolerant to $\mathrm{pH} 10$. Isolates grown within the optimum range of $\mathrm{pH}$ 6-8 were selected. It was reported by several authors that rhizobacteria within the range of 6.57.0 were shown plant growth promotion activity such as phosphate solubilization (Maheshwar et al., 2012). Bacterial isolates were further screened for heavy metal tolerance using three salts of cadmium, lead and zinc. The tolerance level of different bacterial isolates varied greatly. The maximum level of metal tolerance (1 mM- $10 \mathrm{mM}$ ) shown by the potential isolates is presented in Figure 3b, which is in agreement with previous studies reported that rhizobacterial isolates showing metal tolerance activity in the range of 2 mM-8 mM were posses plant growth promotion potential as well as suited for the bioremediation studies (Belimov et al., 2005; Ganesan, 2008). A total of four isolates NU25, NU27, NU36 and NU44 were selected as the most promising potential isolates on the basis of having multiple plant growth promoting characteristics and stress tolerance potential. These potential isolates were further characterized by BIOLOG and metabolic profile of the potential isolates is shown in Table $5 \mathrm{a}-5 \mathrm{~b}$. The neighboring species provided by the database with the maximum similarity index is shown in Table 4. Isolate NU25 and NU36 showed maximum similarity with Acinetobacter sp. and Pseudomonas sp. respectively whereas isolates NU27 and NU44 showed less than $50 \%$ similarity with any of the bacterial strain from the BIOLOG database therefore not identified. 

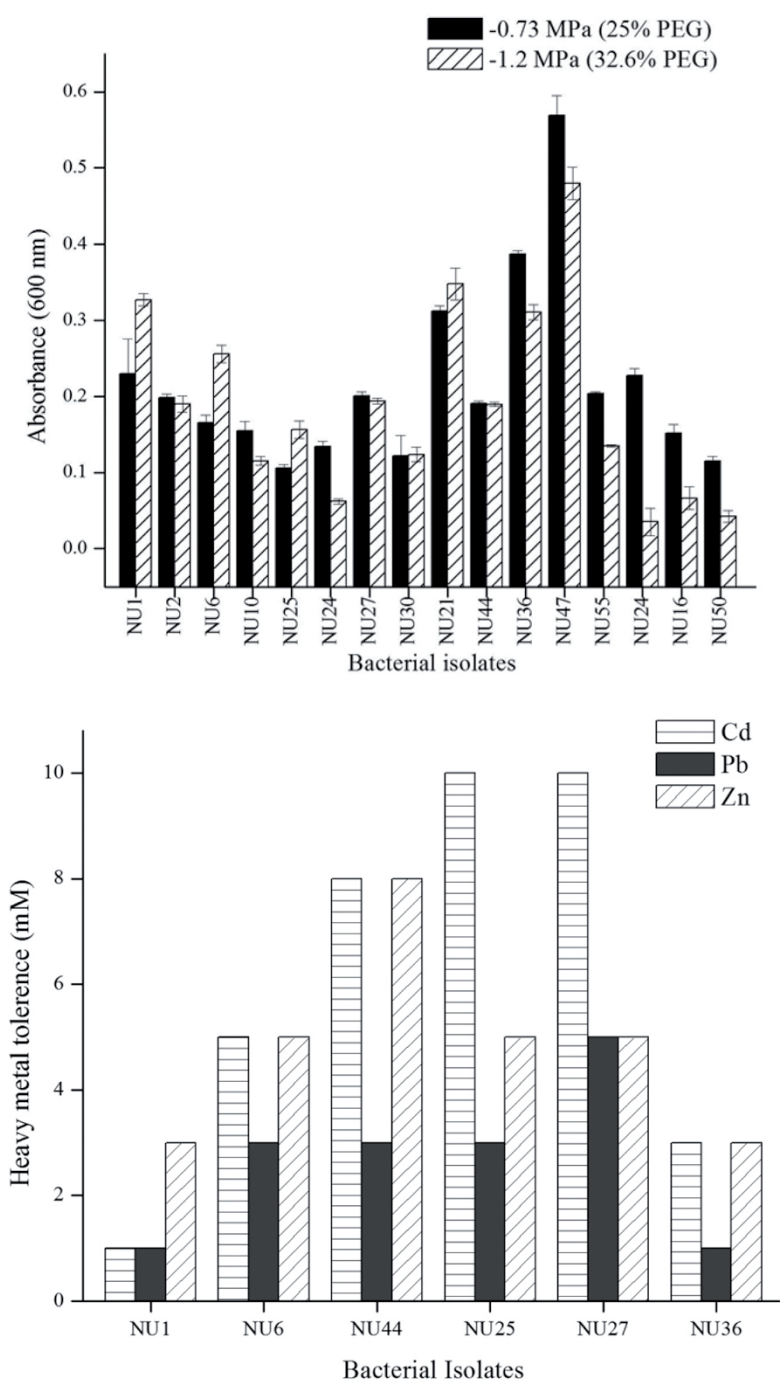

Figure 3 (a) Absorbance of bacterial isolates in at two different PEG6000 concentrations (b) Threshold level of metal tolerance by potential isolates 
Table 5a. Substrate utilization pattern of selected isolates as determined by GEN III Biolog.

\begin{tabular}{|c|c|c|c|c|c|c|c|c|c|c|c|}
\hline \multirow[t]{2}{*}{ No. } & \multirow[t]{2}{*}{ Nutrient source } & \multicolumn{4}{|c|}{ Bacterial Isolates } & \multirow[t]{2}{*}{ No. } & \multirow[t]{2}{*}{ Nutrient Source } & \multicolumn{4}{|c|}{ Bacterial Isolates } \\
\hline & & 36 & 25 & 27 & 44 & & & 36 & 25 & 27 & 44 \\
\hline $\mathrm{A} 1$ & Negative Control & & & & & C1 & $\alpha$-D-Glucose & + & & + & \\
\hline A2 & Dextrin & & & + & & $\mathrm{C2}$ & D-Mannose & & & + & \\
\hline $\mathrm{A} 3$ & d-Maltose & & & + & & $\mathrm{C} 3$ & D-Fructose & & & + & \\
\hline A4 & d-trehalose & + & & + & & C4 & D-Galactose & & & & \\
\hline A5 & d-cellobiose & & & + & $+/-$ & C5 & 3-Methyl Glucose & & & & \\
\hline A6 & Gentibiose & & & + & & C6 & D-Fucose & & & & \\
\hline A7 & Sucrose & & & + & & C7 & L-Fucose & & & & \\
\hline A8 & D-Turanose & & & + & & C8 & L-Rhamnose & & & & $+/-$ \\
\hline A9 & Stachyose & & & & & C9 & Inosine & & & & \\
\hline A10 & Positive Control & + & + & + & + & C10 & $1 \%$ Sodium Lactate & + & + & + & \\
\hline A11 & $\mathrm{pH} 6$ & + & + & + & + & C11 & Fusidic acid & & & & + \\
\hline A12 & $\mathrm{pH} 5$ & & & & & C12 & D-Serine & $+/-$ & + & & + \\
\hline B1 & D-Raffinose & & & + & & D1 & D-Sorbitol & & & + & \\
\hline B2 & $\alpha$-D-Lactose & & & & & D2 & D-Mannitol & & & & \\
\hline B3 & D-Melibiose & & & & & D3 & D-Arabitol & & & & \\
\hline B4 & $\beta$-Methyl-D- Glucoside & & & + & & D4 & Myo-Inositol & + & & & \\
\hline B5 & D-Salicin & & & + & & D5 & Glycerol & & & & \\
\hline B6 & $\begin{array}{l}\text { N-acetyl-d- } \\
\text { glucosamine }\end{array}$ & & & + & & D6 & D-Glucose-6- $\mathrm{PO}_{4}$ & & & & \\
\hline B7 & $\begin{array}{l}\mathrm{N} \text {-acetyl- } \beta-\mathrm{d}- \\
\text { mannosamine }\end{array}$ & & & & & D7 & D-Fructose-6- $\mathrm{PO}_{4}$ & & & & \\
\hline
\end{tabular}


Table 5b. Substrate utilization pattern of selected isolates as determined by GEN III Biolog.

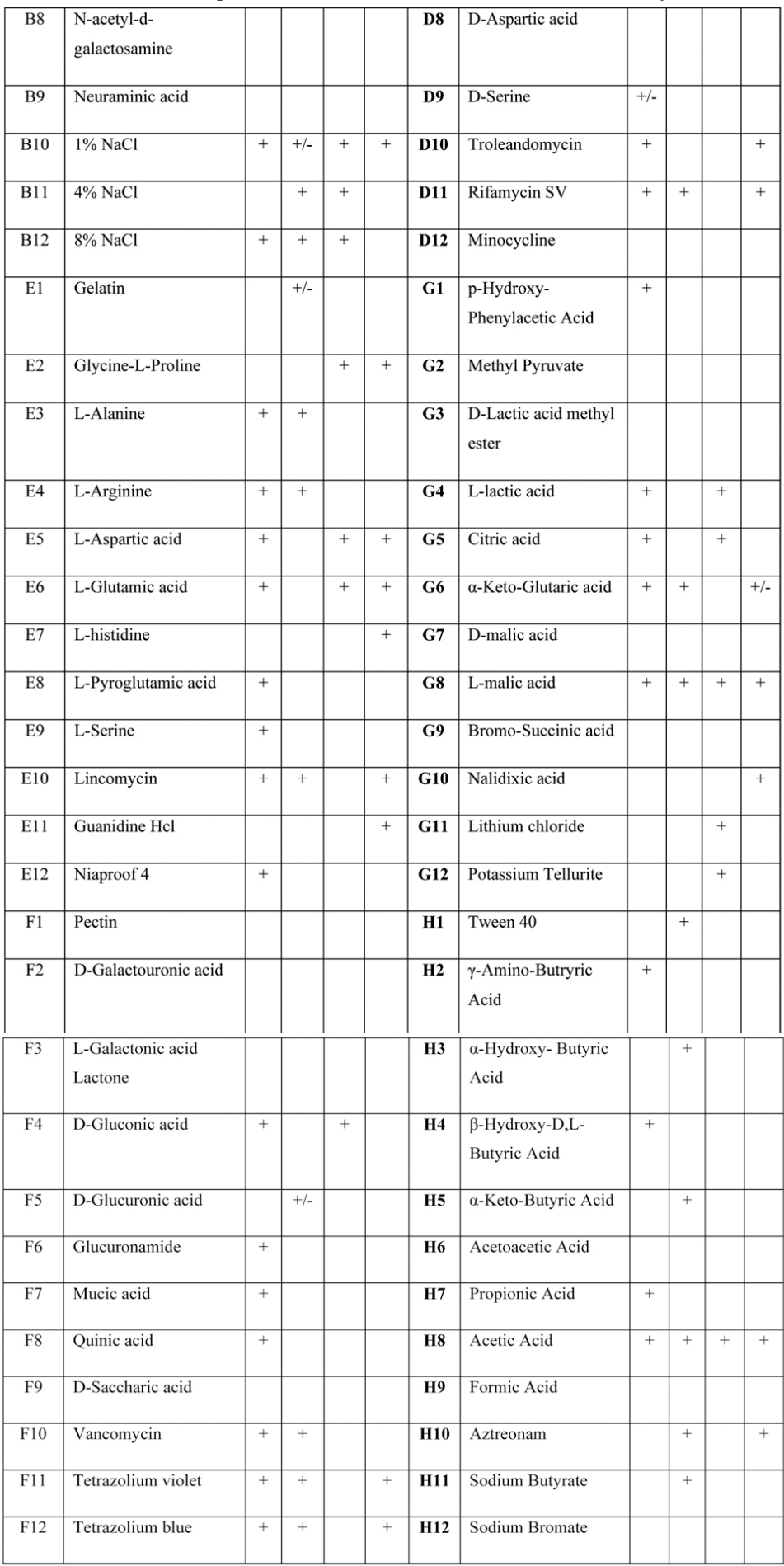




\section{Discussion}

Soil health is maintained by balancing soil biological and physico-chemical properties in a unique concentration. Assessment of soil health hence requires indicators of all these factors. Healthy soils are foremost for the integrity of terrestrial ecosystems to remain intact or to get better from disturbances (Das and Varma, 2011). Deterioration of soil, and thereby soil health, is of concern for human, animal, and plant health. Our study aims to examine the impacts of coal mining on soils of mining sites and associated environment. A survey was performed for the selected mining sites and surrounding environment for analyzing plant diversity and collection of soil samples. Two species viz., Acacia mangium and Acacia catechu were observed as the most dominant species of the tree community at all the sites (Table 1a-1b). Acacia mangium is not native to India but introduced in India in the mid 1960s and became prevalent at mining locations (Krisnawati et al. 2011). High IVI of A. mangium and A. catechu suggested its growth under a wide range of environmental variables. This result suggests that a species having maximum diversity have potential to acclimatize to stress conditions originated due to coal mining activities. As variations in environmental factors the adaptive abilities of organisms, only those species which are adapted to new conditions or those which can become accustomed to the new conditions, participate in the community formation (Agrawal and Agarwal 2000). The species vulnerable to the altered soil properties became diminished and more tolerant species become widespread (Buma and Wessman 2013). Altered soil properties in the area due to coal mining activities modified the response of the vegetation either by acting synergistically or antagonistically. In comparison to the surrounding sites of mining region, dump sites were deprived of any plant species. The Shannon's Diversity Index represents the species richness and diversity in a structure and higher value of H' signifies greater diversity in the area. It was previously reported that any ecosystem having Shannon diversity greater than $2\left(\mathrm{H}^{\prime}>2\right)$ has been regarded as medium to high diverse regarding to species (Barbour et al., 1999). The stability of the community is related to the species diversity, the higher the value of the diversity index, the greater will be the stability of community structure and function (McCann, 2000). Coal mining activities had a negative influence on species composition and diversity as it clearly shown that the no plant species were observed at dump sites which eventually affects the soil characteristics of the nearby surroundings. From the results it is clearly demonstrated that soil characteristics vary greatly between the natural soils and the dump soils. Dump soils are characterized as having less bacterial diversity in comparison to native soils which is in accordance with other authors (Mitrovica et al., 2013). Maximum numbers of bacterial colonies were observed in comparison with the fungal population which is in agreement with the previous studies (Osazee, 2013). Dump soils were found to be associated with high fungal count than the rhizospheric and non rhizospheric soils because of the acidic nature of dump soils. The abundance of microbes in soil indicates a healthy and nutritive soil and suitable for plant growth. The quantity and activity of soil microbes reflect the soil conditions and level of soil development.

The textural analysis of soil samples exhibit that the dump soils contains considerably an extended amount of sand particles and majority of dump soils were characterized as sandy clay loam. The plant root exudates have the potential to disintegrate the coarse particles into smaller particles such as clay (Banerjee, 2000) and the percentage of clay is important for maintaining soil aggregation and structure (Gregorich et al., 1991; Nyles and Ray, 1999). Least percentage of clay was recorded in soil DM1 which is of sandy 
loam texture that is less suitable for plant growth. It was reported earlier that soil texture was used as an indicator of soil microbial characteristics in ecosystem as it influences soil microbial diversity and activity (Jha and Singh, 2011). The native soils collected from natural forest have maximum percentage of clay particles than the dump soils which is due to the presence of vegetation in natural forest. Nyles and Ray (1999) stated that soil samples having high sand content with lower clay content may contain leaching pollutant. It was observed that dump soils were less stable than the natural soils. The bacterial diversity of soils is influenced by the particle size distribution and it was reported that clay fraction has more diverse bacterial population than sand and silt fractions (Faoro et al., 2010; Sessitsch et al., 2001). The present study suggests that dump soils has a relatively low $\mathrm{pH}$ as compare to native soils. The $\mathrm{pH}$ of soils varied from alkaline to acidic. The alkaline $\mathrm{pH}$ indicates optimal range for plant growth but a lower $\mathrm{pH}$ cause problem for normal growth of the plants and it has been proved that soil $\mathrm{pH}$ was improved by the revegetation process (Jha and Singh, 2011; Yang et al., 2015 ). It was reported previously that due to deposition of excessive mineral during mining, soil turn out to be acidic (Jha and Singh, 2011; Harun et al., 2014). The low pH indicates that majority of the soils turns to be acidic due to pyrite oxidation found in coal that controls the lowering of $\mathrm{pH}$ which may be the reason of that restricts the growth of vegetation cover in dump mining soils. On comparing the physicochemical properties of dump and native soils, dump soils are characterized as degraded soils due to excessive $\mathrm{pH}$ and less nutritive content. Therefore, it necessary to reclaim the mining soils with the help of stress tolerant and dominant plant species.

Soil enzymes are a part of soil microorganism and plant involved in the functioning of soil by maintaining nutrient cycle, decomposition of organic matter other pollutant and appeared to be more informative as they play an important role in maintaining soil health. The dehydrogenase activity is used as an indicator of microbial activity in soils as they participate in the electron transport chain and its activity is dependent on the utilization of the intracellular environment of microbes (Kandler et al., 2007). It was observed that in the dump soils DHA activity is found to be low as compared to the soils of natural forest, which indicates the absence of microbial populations in dump soils. The presence of high DHA activity in natural soils rather than dump soils indicates the presence of high microbial diversity in native soils which is also in agreement with the of Reddy et al., (1987) which suggested that dehydrogenase activity is high in native soil due to the presence of microbial diversity in rhizosphere of plant. Urease activity is highly associated with the vegetation of the soil which is also proven by the current study where high activity was observed in vegetative soils (Reddy et al., (1987). In the dump soils urease activity was found to be less due to the absence of plant cover in dump sites. Speier et al., (1980) concluded that urease activity is tending to be constant for soils with vegetation but it is decreased consistently in follow soils. Most often highest catalase activity is found in litter and humus rich surface and therefore maximum catalase activity was found in dump soils. Phosphatase activity indicates the metabolic state of soil thus relates with the biological activity of microbes and used as a good indicator of soil fertility. Maximum activity was observed in native soil which indicates the presence of dynamic microbial activity in the native soil of plants in comparison to dump soils which is found in agreement with the previous studies (Mitrovica et al., 2013). Plant growth promoting rhizobacteria has gained worldwide recognition and an acceptance for soil remediation as well as for sustainable agriculture (Saharan and Nehra, 2011). It was quite evident from 
the study that coal mining deteriorates soil quality, destroys surface vegetation and eventually creates a stressful environment for the survival of plants and microbes. Therefore, it is necessary to reclaim the soil characteristics of degraded dump soil with the help of eco-remediation approach. Study proposed by Yang et al., 2015 proved that restoration and revegetation of mining soils results in the enhancement of soil properties, such as soil organic carbon, bulk density and water content (Yang et al., 2015). Therefore, it is important to select effective PGPR isolates with stress tolerant potential which will enhance plant growth modifies soil characteristics. In addition the PGPR application also reduces the deleterious effect of chemical fertilizers and pesticides. Survival of an inoculated bacterial strain within the rhizosphere is affected by a number of abiotic factors such as high salt, high $\mathrm{pH}$, and high temperature (Johri et al., 1999). Therefore, an attempt was made to screen promising bacterial isolates of with abiotic stress tolerance and PGPR activity for better plant growth promotion.

For the screening of effective PGPR strain, three methods were simultaneously employed. These approaches included screening of rhizobacteria for in vitro IAA production siderophore production and the potential to solubilize inorganic phosphate. In the present study, out sixty four isolates, 28 isolates were found to be positive for phosphate solubilization and approximately $80 \%$ of the isolates were positive for IAA production. Maximum IAA production was exhibited by isolates NU20, NU25, NU27, NU36 and NU47. Isolate NU51 isolated from dump has produced IAA with a concentration of $34.699 \mu \mathrm{g} / \mathrm{ml}$. It was reported earlier that several bacterial species belonging to mine tailing region were produced IAA in the range of 2.2-83.05 $\mu \mathrm{g} / \mathrm{ml}$ (Yu et al., 2014). Our findings of IAA production in soil isolates are in agreement with other workers (Mitrovica et al., 2013; Benidire et al., 2016). The result showed that only three isolates have the potential to produce siderophore in CAS agar medium. It was reported previously that PGPR strains having siderophore production fulfill the iron availability to plants (Saharan, 2011). The result indicates that the out of 64 tested isolates; some isolates exhibit more than two or three PGP activities which may promote plant growth directly, indirectly, or synergistically. The results are similar to previous findings where multifarious plant growth promoting activities among PGPR have been reported (Dey et al., 2004; Singh et al., 2014).

The successful deployment of bacterial isolates in degraded as well as stressed ecosystem depends on their potential to tolerate and propagate under the adverse environmental condition such as high temperatures, drought, salt stress, $\mathrm{pH}$, heavy metal toxicity, and so forth. Out of 64 isolates, twenty two isolates were found to tolerate a water potential of $-0.73 \mathrm{MPa}(25 \%$ PEG 6000) and 19 isolates grown at -1.2 MPa water potential. The maximum tolerance was shown by the isolates NU47. In the present study bacterial isolates growing at a temperature ranged between $30-40{ }^{\circ} \mathrm{C}$ were selected for further studies. A number of studies reported that the optimum temperature range for the growth of plant growth promoting rhizobacteria is 25$35^{\circ} \mathrm{C}$ (Ali et al., 2009). The salt and $\mathrm{pH}$ tolerance potential of bacterial isolates was also screened to select the efficient bacterial isolates. Salinity is an important environmental stress that decreases the plant growth. Tolerance to salt stress represents the ability of bacteria to respond and adapt the environmental changes. Out of 64 bacterial isolates nineteen isolates growing at a salt concentration of $10 \%$ were selected as salt tolerant bacterial isolates. Some of the researcher observed that bacterial isolates promote plant growth at a salt concentration of 5-6\% (Sandhya et al., 2009). Mining processes generates metal pollutants in soil and results in the establishment of metal tolerant microbial population. In the present study majority of the isolates were registered as cadmium and lead tolerant whereas only 
few isolates were found to be zinc tolerant. Recent studies shows that metal tolerance activities were coupled with plant growth promotion activities primarily with siderophore production and they are proved as a potential rhizoremediators (Khan et al., 2009; Tak et al., 2013). It has also been reported that plant growth promoting rhizobacteria have potential to increase plant tolerance towards drought (Vurukonda et al., 2016; Kaushal and Wani, 2016) as well as to ameliorate heavy metal stress (Khan et al., 2009; Tak et al., 2013). Drought and salinity are the most common abiotic stress that adversely affects the plant growth and development. Therefore, bacterial isolates selected on the basis of their potential to survive in stress as well as having plant growth promotion activity for further reclamation and restoration studies. Out of sixty four bacterial isolates, four isolates (NU25, NU27, NU36 and NU44) were selected on the basis of their stress tolerance and plant growth promotion potential. Bacterial isolates where characterized biochemically through BOILOG and it was observed that all the potential isolates differed in the utilization of carbon and nitrogen sources and are functionally divergent.

\section{Conclusion}

The study presented here emphasize on the comparison of various soil samples collected from both the mining sites and from the native forest to evaluate the impact of coal mining on soil quality. The study revealed that the dump soils that belong to mining regions were characterized as having less nutritional content and devoid of any vegetation, as a result soil has acidic $\mathrm{pH}$, less enzymatic activities and low bacterial communities which makes the soil less fertile, whereas all the native soils collected from the surrounding forest are much fertile due to its high nutritional status. Therefore, it is difficult to revegetate the dumps because of extremely poor conditions of the soil and the biological reclamation does not take place within the shelf life of soil as the nutrient cycle gets destroyed and the soil eventually becomes unproductive. In our findings, Acacia mangium was found to be the dominant species and a high number of bacterial communities were recorded in the native soils associated with the plant, out of which a significant percentage of the bacterial isolates were characterized having plant growth promoting potential and stress tolerance properties. Therefore, it is evident from the study that the plant and microbial community has considerably influenced the soil fertility and may be effective in reclaiming soil properties. The present study leads to the delivery of promising bacterial isolates i.e. NU25, NU27 and NU36 which belonged to the natural habitat of mining having maximum potential to release plant growth promoting substances and survive in various stress conditions. Furthermore, the isolates along with dominantly growing plant species will go a long way to reclaim and remediate the soil properties of the mine dump soils of Sonbhadra, Uttar Pradesh.

\section{Acknowledgement}

The authors are thankful to Department of Biotechnology, Govt. of India for providing financial assistance and Director, Motilal Nehru National Institute of Technology, Allahabad for providing research facilities.

\section{References}

Agrawal, S.B., Agarwal, M. 2000. Environmental pollution and plant responses. CRC Press, Boca Raton

Banerjee, M.R., Burton, D.L., McCaughey, W.P., Grant, C. 2000. Influence of pasture management on soil biological quality. Journal of Range Management. 53, 127-133. 
Barbour, M.G., Burk, J.H., Pitts, W.D., Gillam, F.S., Schwartz, M.W. 1999. Terrestrial plant ecology, 3rd edition Benjamin Cummings, an Imprint of Addison Wesley Longman, Inc., Menlo Park, California 189-195.

Belimov A.A., Hontzeas, N., Safronova, V.I., Demchinskaya, S.V., Piluzza, G., Bullitta, S., Glick, B.R. 2005. Cadmium-tolerant plant growthpromoting bacteria associated with the roots of Indian mustard (Brassica juncea L. Czern. Soil Biology and Biochemistry. 37(2), 241-250

Bell, F.G., Bullock, S.E.T., Hälbich, T.F.J., Lindsay, P. 2001. Environmental impacts associated with an abandoned mine in the Witbank Coalfield, South Africa. International Journal of Coal Geology. 45(2), 195-216.

Benidire, L., Pereira, S.I.A., Castro, P.M.L. 2016. Assessment of plant growth promoting bacterial populations in the rhizosphere of metallophytes from the Kettara mine, Marrakech. Environ Sci Pollut Res.

Borpujari, D. 2008. Studies on the occurrence and distribution of some tolerant plant species in different spoil dump of Tikak opencast mine. The Ecoscan. 2(2), 255-260.

Buma, B., Wessman, C.A. 2013. Forest resilience, climate change, and opportunities for adaptation: a specific case of a general problem. For Ecol. Manag. 306, 216-225

Chaulya, S.K., Singh, R.S., Chakraborty, M.K., Tewary, B.K. 2000. Bioreclamation of coal mine overburden dumps in India, Land Contamination \& Reclamation. 8, 189-199.

Curtis, J., McIntosh, R. 1950. The Interrelations of Certain Analytic and Synthetic Phytosociological Characters. Ecological Society of America. 31, 434 455.

Das, S.K., Varma, A. 2010. Role of enzymes in maintaining soil health. In: Soil Enzymology Springer Berlin Heidelberg. pp. 25-42
Faoro, H., Alves, A.C., Souza, E.M., Rigo, L.U., Cruz, L.M., Al-Janabi, S.M., Monteiro, R.A., Baura, V.A., Pedrosa, F.O. 2010. Influence of soil characteristics on the diversity of bacteria in the Southern Brazilian Atlantic Forest. Applied and Environmental Microbiology. 76: 14, 4744-4749.

Ganesan, V. 2008. Rhizoremediation of Cadmium Soil Using a Cadmium-Resistant Plant GrowthPromoting Rhizopseudomonad. Current Microbiology. 56, 403-407.

Ghosh, B., Bajaj, J.C., Hassan, R., Singh, D. 1983. Laboratory manual for soil and water testing, Division of Soil Science and Agricultural Chemistry, IARI, New Delhi, India 11-22.

Harley, P., Prescott, L.M. 2002. Laboratory Exercises in Microbiology, Fifth edition, New York: Mac Graw Hill, 449.

Harun-Or-Rashid, S.M., Roy, D.R., Hossain, M.S., Islam, M.S., Hoque, M.M.M., Zannat Urbi, Z. 2014. Impact of coal mining on soil, water and agricultural crop production: a cross-sectional study on Barapukuria coal mine industry, Dinajpur. Bangladesh. J. Environ. Sci. Res. 1(1), 1-6.

Hazarika, P., Talukdar, N.C., Singh, Y.P. 2006. Natural colonization of plant species on coal mine spoils at Tikak Colliery, Assam. Tropical Ecology. $47,37-46$.

Hossain, M.N., Paul, S.K., Hasan, M.M. 2015. Environmental impacts of coal mine and thermal power plant to the surroundings of Barapukuria, Dinajpur, Bangladesh. Environmental monitoring and assessment, 187(4),1-11.

Jha, A.K., Singh, J.S. 2011. Spoil characteristics and vegetation development of an age eries of mine spoils in a dry tropical environment. Vegetatio. 97, 63-76.

Johri, J.K., Surange, S., Nautiyal, C.S. 1999. Occurrence of salt, $\mathrm{pH}$, and temperature-tolerant, phosphate-solubilizing bacteria in alkaline soils. Current Microbiology. 39, 89-93. 
Joshi, B.H., Modi, K.G. 2013. Screening and Characterization of Heavy Metal Resistant Bacteria for Its Prospects in Bioremediation of Contaminated Soil. J Environ Res Develop 7, 1531-1538.

Kalra, Y.P., Maynard, D.G. 1991. Methods Manual for Forest soil and Plant Analysis. Edmonton, Canada: Minster of supply and services. $125 \mathrm{pp}$.

Kandeler, E., Gerber, H. 1988. Short-term assay of soil urease activity using colorimetric determination of ammonium. Biology and Fertility of Soils. $6,68-72$.

Kaushal, M., Wani, S.P. 2016. Plant-growth-promoting rhizobacteria: drought stress alleviators to ameliorate crop production in drylands. Annals of Microbiology. 66 (1), pp.35-42.

Khan, M.S., Zaidi, A., Wani, P.A., Oves, M. 2009. Role of plant growth promoting rhizobacteria in the remediation of metal contaminated soils. Environmental Chemistry Letters. 7, 1-19.

Krisnawati, H., Maarit, K., Markku, K. 2011. Acacia mangium Willd: ecology, silviculture and productivity. CIFOR.

Loper, J.E. 1986. Influence of Bacterial Sources of Indole-3-acetic Acid on Root Elongation of Sugar Beet. Phytopathology. 76, 386.

Maharana, J.K. 2013. Characterization of Physicochemical Properties and their Impact on Enzyme Activities in a Chronosequence Coal Mine Overburden Spoil as Biomarker of Reclamation Process. Journal of Bacteriology \& Parasitology. 04.

Maheswar, N. U., Sathiyavani, G. 2012. Solubilization of phosphate by Bacillus Sps, from groundnut rhizosphere (Arachis hypogaea L). Journal of Chemical and Pharmaceutical Research. 4, 4007-4011.

McCann, K.S. 2000. The diversity-stability debate. Nature. 405, 228-233.
Merino, C., Nannipieri, P., Matus, F. 2015. Soil carbon controlled by plant, microorganism and mineralogy interactions. Journal of Soil Science and Plant Nutrition. 15, 321-332.

Mitrovica, K. 2013. Plant and microbial diversity in coal mine-affected soil in 'Kakanj' (Bosnia and Herzegovina). 078, 403-408.

Munishi, P.K.T., Philipina, F., Temu, R.P.C., Pima, N.E. 2008. Tree species composition and local use in agricultural landscapes of west Usambaras Tanzania. African Journal of Ecology. 46, 66-73.

Nyle, C.B., Ray, R.N. 1999. The nature and properties of soils. Published by Prentice Hall Upper Saddle River, New Jersey. 565.

Oliveira, A., Pampulha, M.E. 2006. Effects of longterm heavy metal contamination on soil microbial characteristics. Journal of bioscience and bioengineering, 102(3), 157-161.

Osazee, O.J., Obayagbona, O.N., Daniel, E.O. 2013. Microbiological and physicochemical analyses of top soils obtained from four municipal waste dumpsites in Benin City, Nigeria. 1, 23-30.

Premono, M.E., Moawad, A.M., Vlek, P.L.G. 1996. Effect of phosphate-solubilizing Pseudomonas putida on the growth of maize and its survival in the rhizosphere. Indones J. Crop Sci. 11, 13-23.

Rajan, K., Natarajan, A., Anil Kumar, K. S., Badrinath, M. S., Gowda, R. C. 2010. Soil organic carbon - the most reliable indicator for monitoring land degradation by soil erosion. Current Science. 99, 823-827.

Reddy, G. B., Faza, A., Bennett, Jr. R. 1987. Activity of enzymes in rhizosphere and non-rhizosphere soils amended with sludge. Soil Biology and Biochemistry 19, 203-205.

Saharan, B.S. 2011. Plant growth promoting rhizobacteria: a critical review. Life Sciences and Medicine Research. 
Sandhya, V, Sk. Z.A., Grover, M., Reddy, G., Venkateswarlu, B. 2009. Alleviation of drought stress effects in sunflower seedlings by the exopolysaccharides producing Pseudomonas putida strain GAP-P45. Biology and Fertility of Soils. 46, 17-26.

Schwyn, B., Neilands, J.B. 1987. Universal chemical assay for the detection and determination of siderophores. Analytical Biochemistry. 160, 47-56.

Sessitsch, A., Weilharter, A., Martin, H., Kirchmann, H., Kandeler, E., Gerzabek, M.H. 2001. Microbial Population Structures in Soil Particle Size Fractions of a Long-Term Microbial Population Structures in Soil Particle Size Fractions of a LongTerm Fertilizer Field Experiment. Applied and Environmental Microbiology. 67, 4215-4224.

Simonis, A.D., Setatou, H.B. 1996. Assessment of available phosphorus and potassium in soils by the calcium chloride extraction method. Communications in Soil Science \& Plant Analysis. 27(34), 685-694.

Singh, R.K., Kumar, D.P., Singh, P., Solanki, M.K., Srivastava, S., Kashyap, P.L., Kumar, S., Srivastava, A.K., Singhal, P.K., Arora, D.K. 2014. Multifarious plant growth promoting characteristics of chickpea rhizosphere associated Bacilli help to suppress soil-borne pathogens. Plant growth regulation. 73(1), 91-101.

Speir, T.W., Lee, R., Pansier, E.A., Cairns, A. 1980. A comparison of sulphatase, urease and protease activities in planted and in fallow soils. Soil Biology and Biochemistry. 12, 281-291.
Tabatabai, M. A. 1977. Effects of trace elements on urease activity in soils. Soil Biology and Biochemistry. 9, 9-13.

Tak, H.I., Ahmad, F., Babalola, O.O. 2013. Advances in the application of plant growth-promoting rhizobacteria in phytoremediation of heavy metals. In: Reviews of Environmental Contamination and Toxicology .223 (33-52). Springer New York.

Vurukonda, S.S.K.P., Vardharajula, S., Shrivastava, M., Sk.Z, A. 2016. Enhancement of drought stress tolerance in crops by plant growth promoting rhizobacteria. Microbiological Research. $184,13-24$

Whitford, P.B. 1949. Distribution of woodland plants in relation to succession and clonal growth. Ecology. 199-208.

Wong, M. H. 2003. Ecological restoration of mine degraded soils, with emphasis on metal contaminated soils. Chemosphere. 50, 775-780.

Yang, Z., Hao, H.M., Wang, D., Chang, X.F., Zhu, Y.J., Wu, G.L. 2015. Revegetation of artificial grassland improves soil organic and inorganic carbon and water of abandoned mine. Journal of Soil Science and Plant Nutrition. 15, 629-638.

Zhan, X., Wu, W., Zhou, L., Liang, J., Jiang, T. 2010. Interactive effect of dissolved organic matter and phenanthrene on soil enzymatic activities. Journal of Environmental Sciences. 22(4), 607-614. 